Article

\title{
In situ formation of amorphous Fe-based bimetallic hydroxides from metal-organic frameworks as efficient oxygen evolution catalysts
}

\author{
You Xu a,b, Kaili Ren a, Rong Xu b,* \\ a State Key Laboratory Breeding Base of Green-Chemical Synthesis Technology, College of Chemical Engineering, Zhejiang University of Technology, \\ Hangzhou 310014, Zhejiang, China \\ b School of Chemical \& Biomedical Engineering, Nanyang Technological University, 62 Nanyang Drive, Singapore 637459, Singapore
}

\section{A R T I C L E I N F}

\section{Article history:}

Received 31 August 2020

Accepted 22 October 2020

Available online 5 April 2021

\section{Keywords:}

Bimetallic hydroxides

Electrocatalysis

Metal-organic frameworks

Oxygen evolution reaction

Photocatalysis

\begin{abstract}
A B S T R A C T
Oxygen evolution from water driven by electrocatalysis or photocatalysis poses a significant challenge as it requires the use of efficient electro-/photo-catalysts to drive the four-electron oxygen evolution reaction (OER). Herein, we report the development of an effective strategy for the in situ chemical transformation of Fe-based bimetallic MIL-88 metal-organic frameworks (MOFs) into corresponding bimetallic hydroxides, which are composed of amorphous ultrasmall nanoparticles and afford an abundance of catalytically active sites. Optimized MOF-derived NiFe-OH-0.75 catalyst coated on glassy carbon electrodes achieved a current density of $10 \mathrm{~mA} \mathrm{~cm}^{-2}$ in the electrocatalytic OER with a small overpotential of $270 \mathrm{mV}$, which could be decreased to $235 \mathrm{mV}$ when loading the catalysts on a nickel foam substrate. Moreover, these MOF-derived Fe-based bimetallic hydroxides can be used as efficient cocatalysts when combined with suitable photosensitizers for photocatalytic water oxidation.
\end{abstract}

(C) 2021, Dalian Institute of Chemical Physics, Chinese Academy of Sciences. Published by Elsevier B.V. All rights reserved.

\section{Introduction}

Catalytic water splitting to produce hydrogen and oxygen by either electrochemical or photochemical pathways is considered a sustainable energy conversion scheme [1-7]. Regardless of the electrochemical or photochemical approach used for water splitting, the oxygen evolution reaction (OER) is the critical half reaction and requires efficient electrocatalysts/cocatalysts to promote sluggish reaction kinetics [8-20]. So far, $\mathrm{Ru} / \mathrm{Ir}$-based compounds are the most widely used and efficient electrocatalysts for the OER. However, multiple disadvantages, such as high cost, scarce supply, and poor catalytic stability, largely limit their practical applications. Conversely, a single heterogeneous catalyst for achieving both highly efficient electrochemical and photochemical OER is still rarely reported.
Therefore, it is important to develop alternative, active, and earth-abundant electrocatalysts/cocatalysts for the OER.

To enhance the catalytic performance of nanostructured materials, current general strategies are mainly focused on controlling or tuning their size, morphology, structure, crystallinity, and composition, as these factors can greatly affect catalytic properties. As a gas-evolving heterogeneous catalytic reaction, the electrochemical or photochemical OER occurs mainly at the active centers of the catalysts/cocatalysts. Thus, increasing the density and reactivity of the active sites on the electrocatalysts or cocatalysts is considered an effective approach to improve their catalytic activity [21-23]. One effective strategy to boost the catalytic activity of electrocatalysts is tailoring the particle size of nanostructured materials. In this regard, ultrafine or ultrasmall nanoparticles or assembly patterns

\footnotetext{
* Corresponding author. E-mail: rxu@ntu.edu.sg
}

This work was supported by the Nanyang Technological University and the National Natural Science Foundation of China (21701141).

DOI: 10.1016/S1872-2067(20)63741-X | http:// www.sciencedirect.com/journal/chinese-journal-of-catalysis | Chin. J. Catal., Vol. 42, No. 8, August 2021 
have received increasing interest as they can provide more catalytically active sites and higher atom utilization efficiencies than their bulk or large-size counterparts [24-28]. Moreover, recently studies are focusing on controlling the crystallinity of catalysts to optimize their performance [29-33]. Some studies have revealed that low-crystalline or amorphous metal oxides can achieve electrochemical performance better than that of their highly crystalline counterparts, mainly because they exhibit more structural defects and disorders [34-40]. Based on the above discussion, the design and fabrication of low-crystalline or amorphous nanostructured catalysts composed of ultrafine particles or assembly patterns for the OER is highly desirable.

Metal-organic frameworks (MOFs) are very attractive as catalysts owing to their advanced physical and chemical properties, such as high surface areas, ordered structures, tunable porosity, and functionality [41-45]. A few MOFs or MOF-based composites have been directly used as electrocatalysts or electrode materials for electrochemical OERs $[46,47]$. However, for most pure MOF materials, their instability in aqueous conditions and poor electron-conductive properties exclude them from being directly used as catalysts for electrochemical applications. To avoid these crucial drawbacks, MOFs are usually used as sacrificial templates or precursors to be further converted into other derived materials for catalytic water splitting applications [48-52]. A recent report by Tian et al. [53] demonstrated the electric-field-assisted in situ hydrolysis of bulk MOFs into ultrathin metal oxyhydroxide nanosheets with good crystallinity for the efficient electrochemical OER. Despite these advances, the synthesis of well-defined MOF-derived, low-crystalline, or amorphous catalysts composed of ultrafine nanoparticles for both electrochemical and photocatalytic OERs is still rarely reported. Herein, we report the development of a facile strategy for fast in situ conversion of MOFs into alkaline-stable hydroxide catalysts for both electrochemical and photocatalytic OERs. By using Fe-based bimetallic MIL-88 MOFs as the starting materials, the as-mentioned approach enables us to convert the MOF precursor in situ into active OER electrocatalysts that are stable in alkaline environments (Scheme 1). The as-converted Fe-based bimetallic hydroxides can retain the microscopic morphology of the MOF and are composed of ultrasmall nanoparticles as assembly patterns. Such an in situ chemical transformation of MOFs can realize excellent interconnection among the as-formed ultrasmall nanoparticles, resulting in a large electrochemically active area, which facilitates the OER. Moreover, such an in situ conversion strategy can also produce a highly efficient cocatalyst for photocatalytic oxygen evolution by coupling with a $\left[\mathrm{Ru}(\mathrm{bpy})_{3}\right] \mathrm{Cl}_{2}$

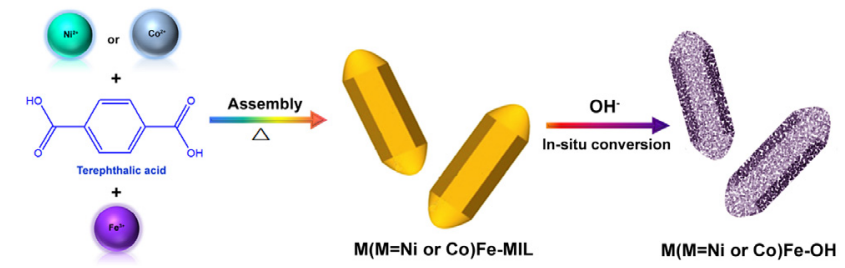

Scheme 1. Schematic illustration of the preparation of the MOF-derived Fe-based bimetallic hydroxides. photosensitizer.

\section{Experimental}

\subsection{Synthesis of NiFe-MIL}

The NiFe-MILs were synthesized by a modified solvothermal method according to a literature procedure [54]. Typically, for the NiFe-MIL-0.75 sample, $\mathrm{FeCl}_{3} \cdot 6 \mathrm{H}_{2} \mathrm{O}$ (1.6 mmol), $\mathrm{Ni}\left(\mathrm{NO}_{3}\right)_{2} \cdot 6 \mathrm{H}_{2} \mathrm{O}$ (1.2 mmol), and 1,4-benzenedicarboxylic acid (2.8 mmol) were dissolved in $\mathrm{N}, \mathrm{N}$-dimethylformamide (DMF, $27 \mathrm{~mL}$ ) and continuously stirred for $15 \mathrm{~min}$. Then, $3 \mathrm{~mL}$ of a $\mathrm{NaOH}$ aqueous solution $(0.4 \mathrm{M})$ was added dropwise to the above solution and stirred for another $15 \mathrm{~min}$. Afterwards, the mixture was sealed in a $50 \mathrm{~mL}$ Teflon-lined autoclave and heated at $130{ }^{\circ} \mathrm{C}$ for $12 \mathrm{~h}$. The resultant MOFs were centrifuged and washed with DMF and ethanol three times, followed by drying in an oven at $50{ }^{\circ} \mathrm{C}$ overnight. The as-obtained sample is denoted as NiFe-MIL-0.75 (Ni/Fe molar ratio $=0.75)$. Similarly, the NiFe-MIL-0.50 and NiFe-MIL-1.0 samples were prepared by following the same procedure using $\mathrm{Ni} / \mathrm{Fe}$ molar ratios of 0.5 and 1.0 , respectively.

\subsection{Synthesis of Fe-MIL}

The synthesis of Fe-MIL was similar to that of the NiFe-MILs, except that no $\mathrm{Ni}\left(\mathrm{NO}_{3}\right)_{2} \cdot 6 \mathrm{H}_{2} \mathrm{O}$ was added.

\subsection{Synthesis of CoFe-MIL-0.75}

The synthesis of CoFe-MIL-0.75 was similar to that of NiFe-MIL-0.75 using $\mathrm{FeCl}_{3} \cdot 6 \mathrm{H}_{2} \mathrm{O}$ and $\mathrm{Co}\left(\mathrm{NO}_{3}\right)_{2} \cdot 6 \mathrm{H}_{2} \mathrm{O}$ as metal precursors, followed by sealing the vessel and heating at $100{ }^{\circ} \mathrm{C}$ for $12 \mathrm{~h}$.

\subsection{Synthesis of NiFe-OH-0.75(H)}

Typically, $50 \mathrm{mg}$ of NiFe-MIL-0.75 was dispersed in $25 \mathrm{~mL}$ of a $\mathrm{KOH}$ aqueous solution $(1 \mathrm{M})$. Then, the dispersion was sealed in a $50 \mathrm{~mL}$ Teflon-lined autoclave and heated at $120^{\circ} \mathrm{C}$ for $5 \mathrm{~h}$. The resultant $\mathrm{NiFe}-\mathrm{OH}-0.75(\mathrm{H})$ was collected and washed with water and ethanol three times, followed by drying at $50{ }^{\circ} \mathrm{C}$ overnight.

\subsection{Conversion of $\mathrm{M}(\mathrm{M}=\mathrm{Ni}, \mathrm{Co}) \mathrm{Fe}-\mathrm{MIL}$ into $\mathrm{MFe}-\mathrm{OH}$}

Taking NiFe-MIL-0.75 as an example, in brief, the NiFe-MIL-0.75 sample ( $4 \mathrm{mg}$ ) was dispersed in a $1 \mathrm{~mL}$ ethanol containing $30 \mu \mathrm{L}$ Nafion solution (5 wt\%) under sonication to form a homogeneous ink. Then, $15 \mu \mathrm{L}$ of ink was coated onto a glassy carbon (GC, diameter $=5 \mathrm{~mm}$ ) electrode and allowed to dry naturally at room temperature. The sample loading on the GC electrode was approximately $0.31 \mathrm{mg} \mathrm{cm}^{-2}$. A clean Pt film and $\mathrm{a} \mathrm{Ag} / \mathrm{AgCl}$ electrode served as the counter and reference electrodes, respectively. The complete conversion of the MOF into hydroxides was performed using cyclic voltammetry (CV) scanning between 1.15 to $1.6 \mathrm{~V}$ ( $v s$. reversible hydrogen elec- 
trode, RHE) in a $1.0 \mathrm{M} \mathrm{KOH}$ solution for 50 cycles. The as-converted sample was denoted as $\mathrm{NiFe}-\mathrm{OH}-0.75$.

To collect a sufficient amount of NiFe-OH-0.75 sample for characterization, a $\mathrm{Ni}$ foam substrate (geometric area $=1 \mathrm{~cm}^{-2}$ ) composed of NiFe-MIL- 0.75 precursors $\left(0.8 \mathrm{mg} \mathrm{cm}^{-2}\right)$ was also used as the working electrode and applied in CV cycling. After complete conversion, the NiFe-OH-0.75 sample was collected and subjected to further characterization.

The conversion of other MFe-MIL precursors into MFe-OHs was achieved using a similar procedure with the corresponding MOF as the starting material.

Information regarding the characterization and electrochemical and photochemical measurements can be obtained from the supporting information.

\section{Results and discussion}

NiFe bimetallic MIL-88 MOFs with various compositions (NiFe-MIL- $n, n$ represents the Ni/Fe molar ratio) were first synthesized by a modified solvothermal method according to the literature [54]. Fig. 1(a) shows the scanning electron microscopy (SEM) image of the NiFe-MIL-0.75 sample, in which a rod-shaped morphology with reducing ends and a smooth surface is evident. The morphological properties of NiFe-MIL-0.75 were further demonstrated by transmission electron micros-
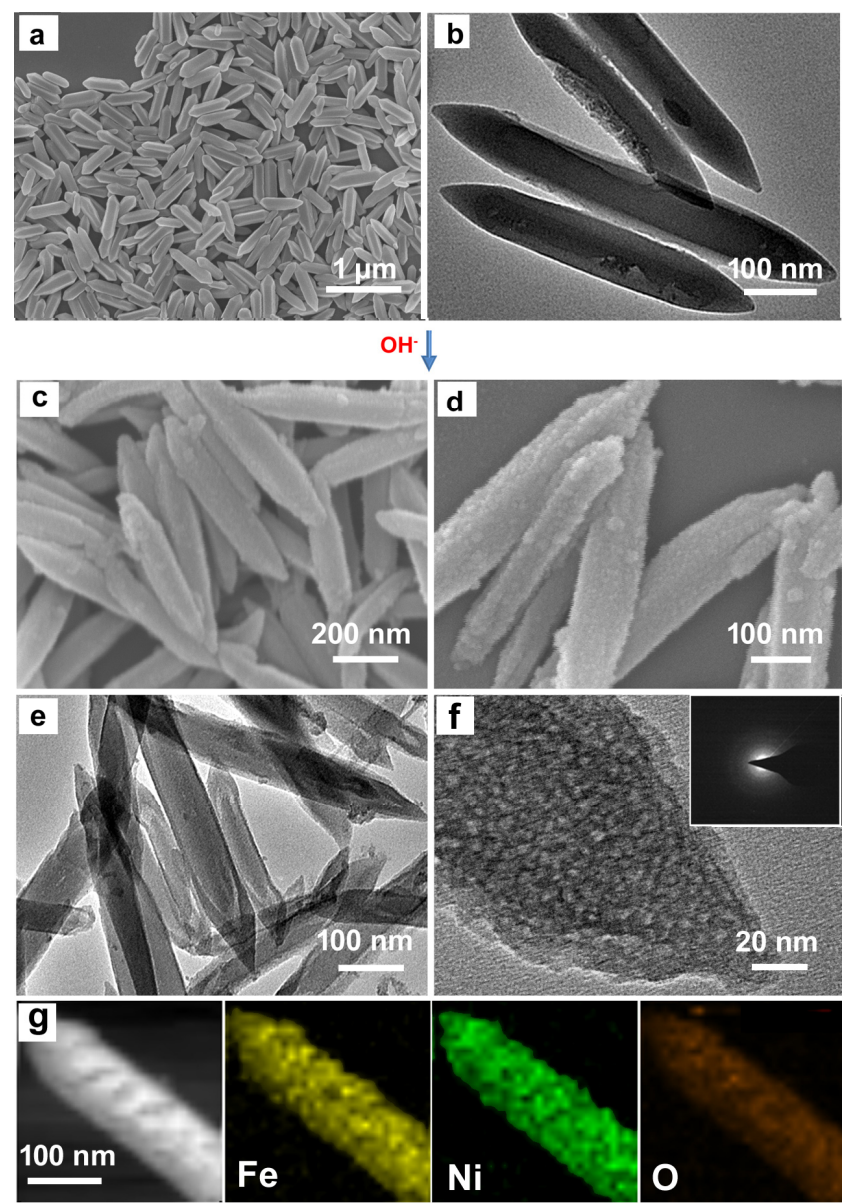

Fig. 1. SEM (a) and TEM (b) images of the NiFe-MIL-0.75. SEM (c,d), TEM (e), HRTEM (f), and HAADF-STEM (g) and elemental mapping images of the as-converted NiFe-OH-0.75. copy (TEM) (Fig. 1(b)). The composition of NiFe-MIL-0.75 was analyzed by energy dispersive X-ray (EDX) spectroscopy, revealing the presence of $\mathrm{Ni}, \mathrm{Fe}, \mathrm{C}$, and $\mathrm{O}$ (Fig. S1). Various NiFe-MIL MOFs can be obtained by adjusting the mole ratio of the metal precursors with a slight difference in the aspect ratio (Fig. S2). Based on the inductively coupled plasma atomic emission spectrometry (ICP-AES) results, the molar ratios of $\mathrm{Ni} / \mathrm{Fe}$ in these NiFe-MILs were very close to those of the starting metal precursors (Table S1).

Using NiFe-MIL-0.75 as the model material, we first loaded the MOF sample on a GC electrode to study the morphology and composition evolutions and the corresponding electrocatalytic properties toward the OER in alkaline conditions (1 M KOH). $\mathrm{CV}$ was performed at a scan rate of $50 \mathrm{mV} \mathrm{s}^{-1}$ to study the electrochemical properties of the materials supported on the GC electrode. From Fig. S3, it can be observed that the sample shows an electrocatalytic response for the OER, and the anodic current increases rapidly by applying a small overpotential. In the potential region higher than $1.45 \mathrm{~V}$ (vs. RHE), an obvious OER response current was observed, indicating that the species on the GC electrode were active toward the OER. By comparing the $\mathrm{CV}$ curves after the $1^{\text {st }}$ and $50^{\text {th }}$ cycles in the potential range of 1.15-1.45 V (vs. RHE) (Fig. S3(b)), it can be found that the current in this potential range increases with an increase in the cycling time. This indicates that more and more sections of the MOF have been converted into hydroxides. Furthermore, it should be noted that the current of the CV curve recorded at the $50^{\text {th }}$ cycle in the potential region higher than $1.47 \mathrm{~V}$ ( vs. RHE) almost coincided with that of the $1^{\text {st }}$ cycle (Fig. S3(a)), suggesting fast conversion of the raw MOFs and stable as-formed $\mathrm{O}_{2}$-evolving catalytic materials on the GC electrode.

To obtain more information about the morphology, structure, and composition, the as-converted materials on the GC electrode were collected and subjected to characterization. Figs. 1(c,d) present representative SEM images of the NiFe-MIL-0.75-derived materials (denoted as NiFe-OH-0.75 accordingly), revealing the retention of the rod-shaped macroscopic morphology with much rougher surfaces compared with the parent MOF material. Upon closer examination by high-magnification SEM and TEM images, it can be seen that these as-converted nanorods are composed of numerous ultrasmall nanoparticles $(<10 \mathrm{~nm})$, as shown in Figs. 1(d,e). The high-resolution TEM (HRTEM) image (Fig. 1(f)) shows that these ultrathin nanoparticles are strongly interconnected with neighboring particles, which ensures good electrical and mechanical contact between the particles. Moreover, no clear lattice fringes were observed in the HRTEM image, suggesting an amorphous structure. The selective-area electron diffraction (SAED) pattern further depicts the amorphous feature (see the inset of Fig. 1(f)). The composition of the as-obtained MOF-derived materials was examined by EDX, indicating that $\mathrm{Ni}, \mathrm{Fe}$, and $\mathrm{O}$ are included in the sample (Fig. S4). Furthermore, the high-angle annular dark-field scanning TEM (HAADF-STEM) images and corresponding elemental mapping confirm the homogeneous distribution of $\mathrm{Ni}, \mathrm{Fe}$, and $\mathrm{O}$ through the whole as-converted nanorod (Fig. 1(g)).

The crystallographic structure and phase composition of 

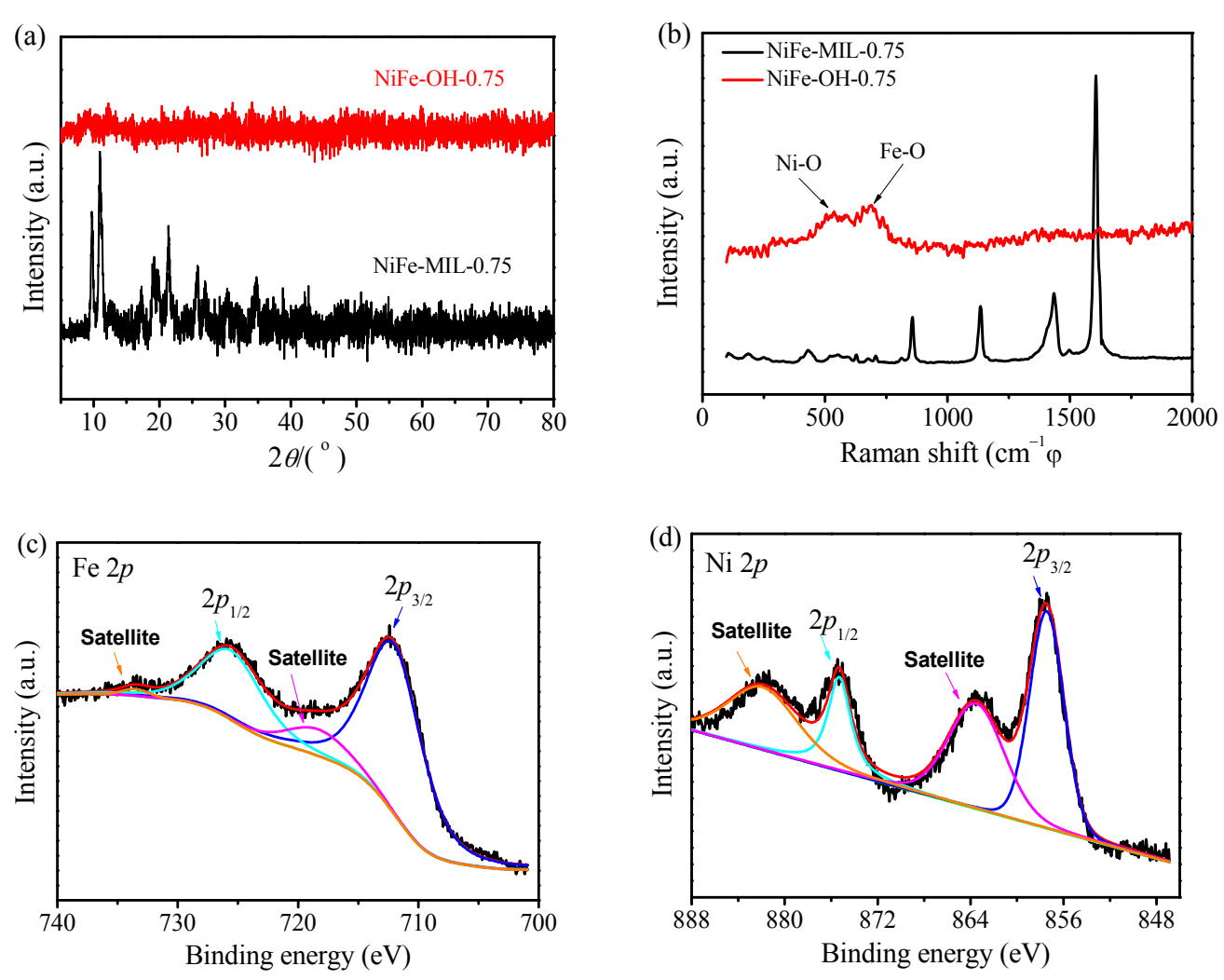

Fig. 2. XRD patterns (a) and Raman spectra (b) of NiFe-MIL-0.75 and the as-converted NiFe-OH-0.75; High-resolution Fe $2 p$ (c) and high-resolution Ni $2 p$ (d) XPS spectra of NiFe-OH-0.75.

these MOF-derived materials were investigated by powder X-ray diffraction (XRD). While the parent NiFe-MIL- 0.75 materials have good crystallinity, the as-converted $\mathrm{NiFe-OH}-0.75$ is mostly amorphous, as indicated by the absence of sharp peaks in the corresponding XRD pattern (Fig. 2(a)). Clearly, the Raman spectrum of the as-converted material is different from that of the parent MOF precursor. Two characteristic bands with intensity maxima at approximately 520.5 and $686.7 \mathrm{~cm}^{-1}$, which correspond to the $\mathrm{Ni}-\mathrm{O}$ and $\mathrm{Fe}-\mathrm{O}$ stretching vibrations [55,56], respectively, are observed (Fig. 2(b)). X-ray photoelectron spectroscopy (XPS) analysis was conducted to investigate the chemical composition and oxidation states of the as-converted products. The presence of $\mathrm{Ni}, \mathrm{Fe}$, and $\mathrm{O}$ in the $\mathrm{NiFe-OH-0.75} \mathrm{sample} \mathrm{was} \mathrm{further} \mathrm{confirmed} \mathrm{by} \mathrm{the} \mathrm{XPS} \mathrm{survey}$ spectrum shown in Fig. S5. As observed in Fig. 2(c), for Ni $2 p$, two main peaks located at 857.5 and $875.4 \mathrm{eV}$ correspond to $\mathrm{Ni}$ $2 p_{3 / 2}$ and $\mathrm{Ni} 2 p_{1 / 2}$, respectively, which are accompanied by two satellite peaks located at 863.6 and $881.9 \mathrm{eV}[57,58]$. These results indicate the presence of the $\mathrm{Ni}^{2+}$ oxidation state. For Fe $2 p$, the spectrum can be fitted to $\mathrm{Fe} 2 p_{3 / 2}$ at $712.5 \mathrm{eV}$ and Fe $2 p_{1 / 2}$ at $725.8 \mathrm{eV}$ with unexpected satellite peaks corresponding to the $\mathrm{Fe}^{3+}$ oxidation state (Fig. 2(d)) $[57,58]$. These results suggest that the NiFe-MIL can be converted in situ to amorphous $\mathrm{NiFe}-\mathrm{OH}$ under alkaline conditions in the presence of an electric field. Further experiments showed that the conversion could also be completed by immersing the bimetallic MIL-88 in a solution of $1.0 \mathrm{M} \mathrm{KOH}$ for $2 \mathrm{~h}$ without the application of an electric field (Fig. S6). Based on these results, it can be deduced that the conversion of the bimetallic MIL MOF structures into hydroxides results from their instability in aqueous alkaline environments. The relatively labile coordination bonds between the metal ions (i.e., $\mathrm{Fe}^{3+}, \mathrm{Ni}^{2+}$, or $\mathrm{Co}^{2+}$ ) and the 1,4-benzenedicarboxylic acid ligands are believed to be responsible for the limited stability of the MOF structure. In aqueous alkaline solutions, attack of the hydroxyl ions $\left(\mathrm{OH}^{-}\right)$ causes destruction of the coordination and release of ligands, which gradually escape from the surface of the newly formed nanoparticles. The combination of metal ions and $\mathrm{OH}^{-}$results in the in situ formation of metal hydroxide structures. Such transformation can be accelerated under electrochemical OER operating conditions, mainly because the presence of an electrical field is more conducive to the adsorption of $\mathrm{OH}^{-}$and the lower coordination bond strength during electrochemical reactions [53].

The above results suggest that the parent NiFe-MIL MOFs can serve as a self-template to produce $\mathrm{NiFe}-\mathrm{OH}$ by means of in situ chemical conversion in an alkaline environment. Unlike traditional chemical synthetic strategies, this in situ conversion strategy can produce ultrasmall amorphous nanoparticles, which can maintain excellent electrical interconnections among them. Importantly, such a self-template strategy allows us to tune the composition of the as-converted products by controlling the composition of the starting MOF materials (Fig. S7). Furthermore, we demonstrate that this facile conversion strat- 

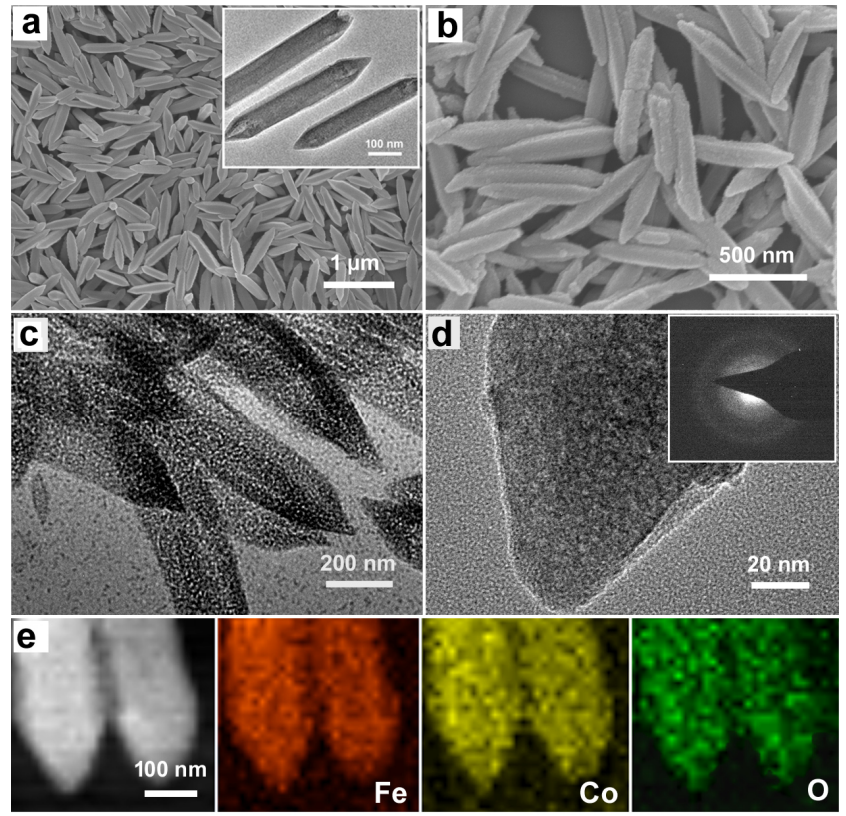

Fig. 3. SEM image (a) of the CoFe-MIL-0.75. The inset of (a) is the TEM image of CoFe-MIL-0.75. SEM (b), TEM (c), HRTEM (d), and HAADFSTEM (e) images and element mapping images of the CoFe-OH-0.75. The inset of (d) is the SAED pattern of the CoFe-OH-0.75.

egy is also applicable for the preparation of other Fe-based bimetallic hydroxides by using the corresponding MOF as the starting material. For example, CoFe-MIL-0.75 was used as the starting material for CV scanning between 1.15 to $1.60 \mathrm{~V}$ ( $v s$. RHE) in $1.0 \mathrm{M} \mathrm{KOH}$ for 50 cycles; CoFe-OH-0.75 counterparts composed of amorphous ultrasmall nanoparticles could be obtained, as characterized by SEM, TEM, HRTEM, HAADF-STEM, XRD, and Raman spectroscopy (Fig. 3 and Fig. S8).

With these structural and compositional information in mind, we systematically evaluated the electrocatalytic performance of these in situ as-converted $\mathrm{NiFe-OH}$ materials toward the OER in a $1.0 \mathrm{M} \mathrm{KOH}$ aqueous solution. The OER polarization curves were recorded using linear sweep voltammetry (LSV). For comparison, the catalytic activity of a commercial $\mathrm{IrO}_{2}$ catalyst was also evaluated. Fig. 4(a) shows the OER polarization curves for various catalysts loaded on the GC electrode substrate. Clearly, the NiFe-OH-0.75 catalyst exhibits a better OER catalytic activity than that of the commercial $\mathrm{IrO}_{2}, \mathrm{Fe}-\mathrm{OH}$, and other NiFe-OH catalysts. To yield $10 \mathrm{~mA} \mathrm{~cm}^{-2}$, the NiFe-OH-0.75 catalyst requires an overpotential of $270 \mathrm{mV}$, which is lower than that of $\mathrm{Fe}-\mathrm{OH}(360 \mathrm{mV}), \mathrm{NiFe}-\mathrm{OH}-0.5$ (309 $\mathrm{mV})$, NiFe-OH-1.0 (315 mV), and commercial $\mathrm{IrO}_{2}(319 \mathrm{mV})$. Moreover, the value of the Tafel slope ( $\left.39 \mathrm{mV} \mathrm{dec}^{-1}\right)$ is the smallest among the tested catalysts (Fig. 4(b)). The results indicate that the composition of the catalysts could influence the catalytic activity because the synergistic effect of the mixed metal cations could effectively modulate the electronic properties of the active centers. The OER activity achieved over optimized NiFe-OH-0.75 outperforms many previously reported amorphous $\mathrm{Fe} / \mathrm{Ni} / \mathrm{Co}$-based OER electrocatalysts in terms of overpotential and Tafel slope (Table S2). Moreover, the OER activity of the NiFe-OH-0.75 catalyst is also superior to its highly crystalline counterpart comprising larger nanoparticles, which was produced by converting the MOF precursor under hydrother-
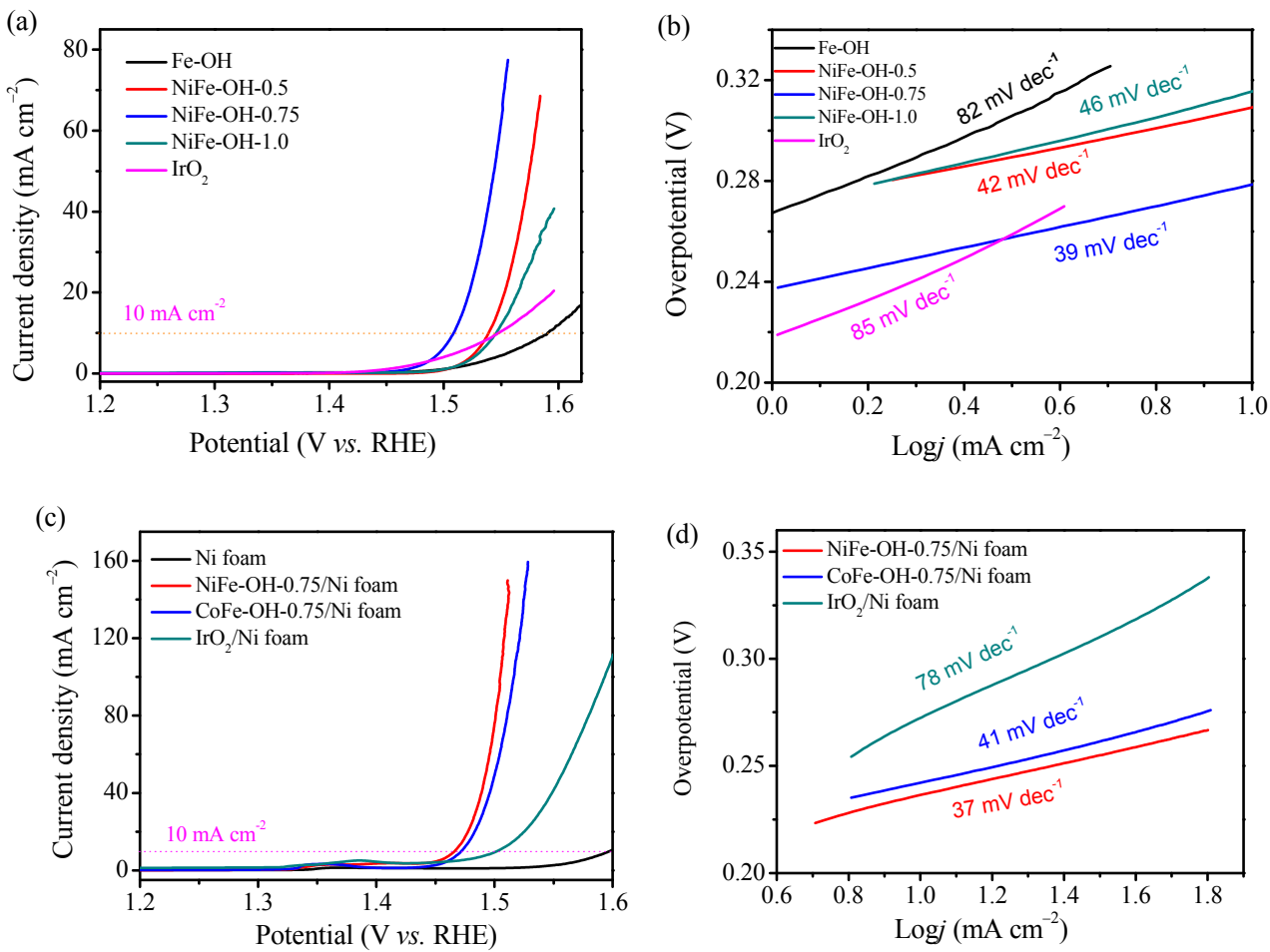

Fig. 4. OER polarization curves $(\mathrm{a}, \mathrm{c})$ and Tafel plots $(\mathrm{b}, \mathrm{d})$ for the various catalysts loaded on different electrode substrates. (a,b) GC electrode; (c,d) nickel foam electrode. 
(a)

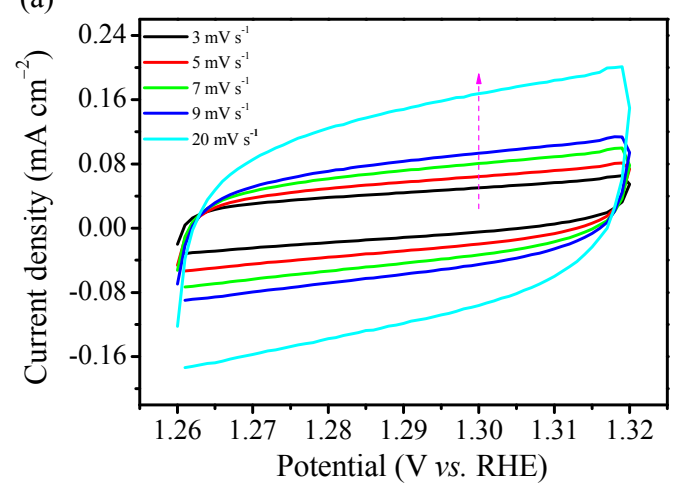

(c)

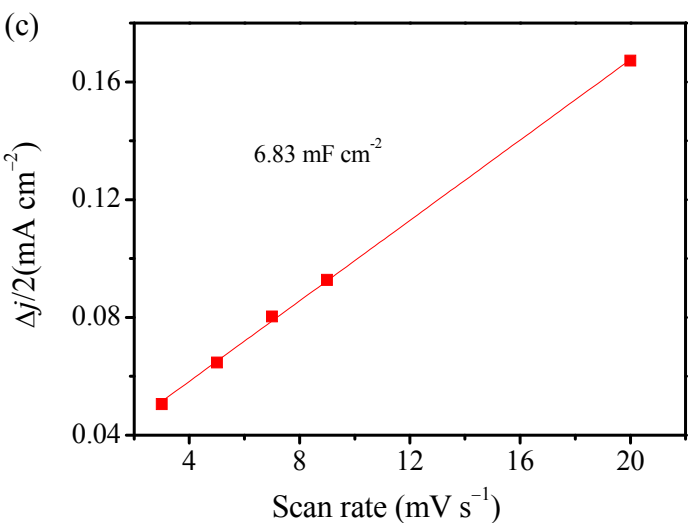

(b)

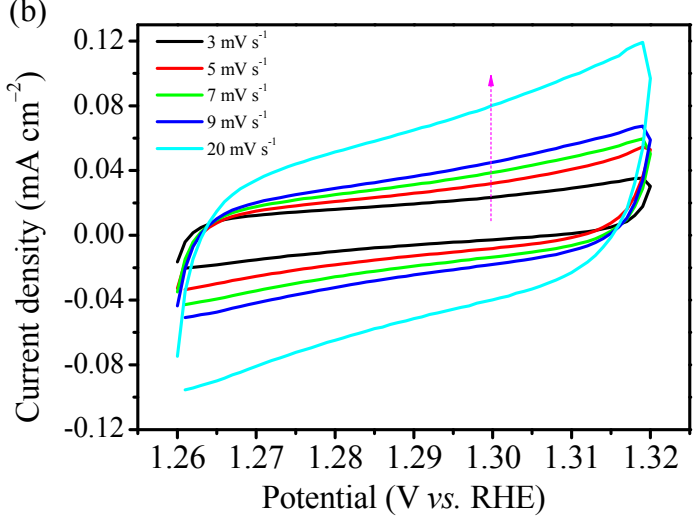

(d)

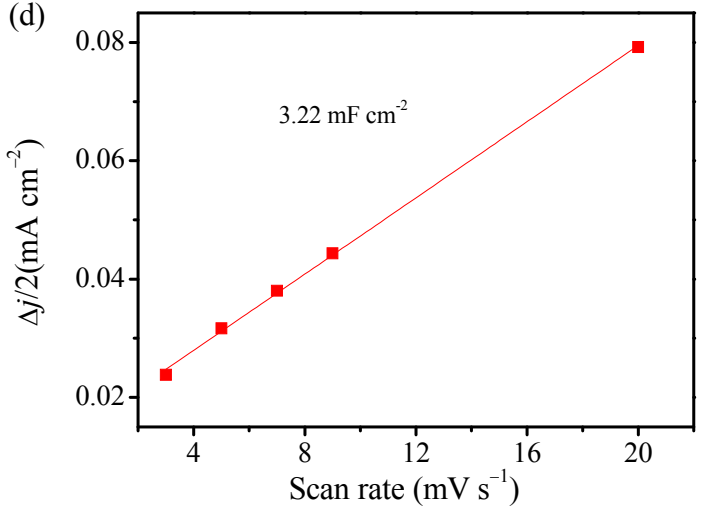

Fig. 5. CV curves at various scan rates and capacitive current densities of the NiFe-OH-0.75 decorated GC electrode (a,c) and NiFe-OH-0.75(H) decorated GC electrode $(b, d)$.

mal conditions (Fig. S9). The enhanced OER activity of the $\mathrm{NiFe}-\mathrm{OH}-0.75$ catalyst composed of amorphous ultrasmall nanoparticles may be ascribed to its larger active surface area, as revealed by the results of the electrochemical double layer capacity measurements (Fig. 5). Deposition of the MOF precursors onto a conductive nickel foam (Ni foam) substrate can result in further enhancement of the OER activity. The $\mathrm{NiFe}-\mathrm{OH}-0.75 / \mathrm{Ni}$ foam electrode requires an overpotential of only $230 \mathrm{mV}$ at $10 \mathrm{~mA} \mathrm{~cm}-2$ (Fig. 4(c)). In addition, the Tafel slope for the NiFe-OH-0.75/Ni foam electrode could be reduced to $37 \mathrm{mV} \mathrm{dec}^{-1}$ (Fig. 4(d)). Assuming that all of the $\mathrm{Ni}$ and $\mathrm{Fe}$ sites inside the as-converted $\mathrm{NiFe}-\mathrm{OH}$ are involved in the OER, we calculated the turnover frequencies (TOFs) of the catalyst to investigate the formation rate of oxygen molecules on the catalytic sites. The optimized NiFe-OH-0.75 catalyst has a TOF of $1.2 \mathrm{~s}^{-1}$ at an overpotential of $300 \mathrm{mV}$, which outperforms those of many previously reported $\mathrm{Ni} / \mathrm{Co} / \mathrm{Fe}$-based catalysts, such as FeCoNiP (0.47 $\mathrm{s}^{-1}$ at $\eta=300 \mathrm{mV}$ ) [59], Fe incorporated $\alpha$ - $\mathrm{Co}(\mathrm{OH})_{2}$ nanosheets $\left(0.027 \mathrm{~s}^{-1}\right.$ at $\left.\eta=300 \mathrm{mV}\right)$ [60], Co-V bimetal hydr(oxy)oxide $\left(0.069 \mathrm{~s}^{-1}\right.$ at $\eta=300 \mathrm{mV}$ ) [61], and NiCo-UMOFNs nanosheets $\left(0.86 \mathrm{~s}^{-1}\right.$ at $\left.\eta=300 \mathrm{mV}\right)$ [42]. Compared with the $\mathrm{NiFe}-\mathrm{OH} / \mathrm{GC}$ electrode, the enhanced performance of the $\mathrm{NiFe}-\mathrm{OH} / \mathrm{Ni}$ foam electrode may be attributed to the excellent conductivity and electron transfer ability of the nickel foam substrate.

Apart from the activity, an electrocatalyst for commercial applications should possess good stability and durability. We performed chronopotentiometric $(V-t)$ tests at $10 \mathrm{~mA} \mathrm{~cm}-2$ for $24 \mathrm{~h}$ to assess the durability of the NiFe-OH-0.75/Ni foam electrode. Fig. 6(a) shows that the NiFe-OH-0.75/Ni foam electrode has good catalytic stability, as the overpotential remains almost constant over $24 \mathrm{~h}$. Moreover, the chronoamperometric (i-t) curve reveals that the OER current density does not suffer evident decay during $24 \mathrm{~h}$ of testing (Fig. 6(b)). These results suggest an excellent catalytic stability and durability for the $\mathrm{NiFe}-\mathrm{OH}-0.75 / \mathrm{Ni}$ foam electrode.

Inspired by their efficient electrocatalytic activity for the OER, we further tested the potential application of these MOF-derived Fe-based bimetallic hydroxides as cocatalysts for photocatalytic water oxidation. This evaluation was performed in an aqueous $\mathrm{KH}_{2} \mathrm{PO}_{4}-\mathrm{K}_{2} \mathrm{HPO}_{4}$ buffer $(\mathrm{pH}=9$ ) by employing
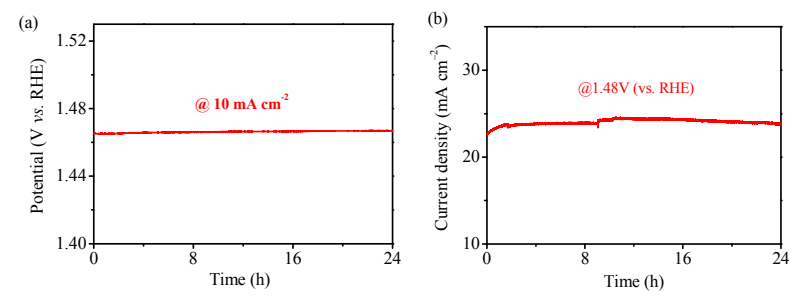

Fig. 6. Time-dependent potential curve (a) and time-dependent current density curve (b) (without $i \mathrm{R}$ compensation) of the $\mathrm{NiFe}-\mathrm{OH}-0.75 / \mathrm{Ni}$ foam electrode. 


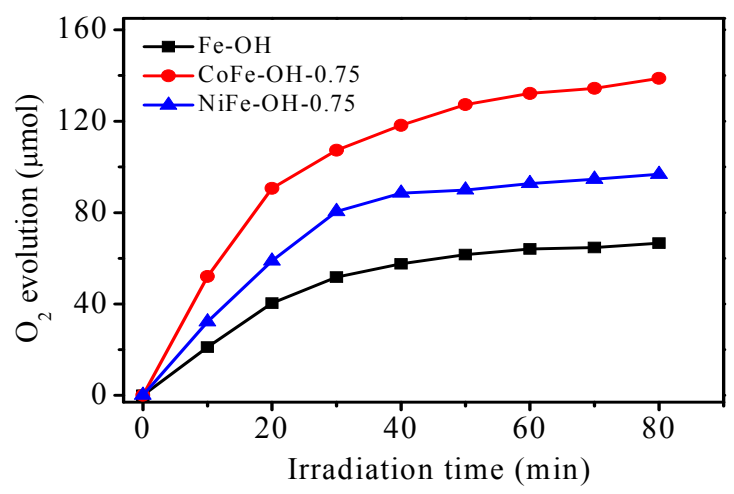

Fig. 7. Time-dependent photocatalytic $\mathrm{O}_{2}$ evolution over various cocatalysts by coupling with a $\left[\mathrm{Ru}(\mathrm{bpy})_{3}\right] \mathrm{Cl}_{2}$ photosensitizer.

the well-established $\left[\mathrm{Ru}(\mathrm{bpy})_{3}\right]^{2+-} \mathrm{S}_{2} \mathrm{O}_{8}{ }^{2-}$ system. In this photocatalytic system, $\left[\mathrm{Ru}(\mathrm{bpy})_{3}\right]^{2+}$ and $\mathrm{S}_{2} \mathrm{O}_{8}{ }^{2-}$ serve as the photosensitizer and electron acceptor, respectively. The details of the $\left[\mathrm{Ru}(\mathrm{bpy})_{3}\right]^{2+-} \mathrm{S}_{2} \mathrm{O}_{8}{ }^{2-}$ photocatalytic cycles have been reported previously $[62,63]$. It was found that these Fe-based bimetallic MIL MOFs could also be transferred into Fe-based bimetallic hydroxides in an aqueous $\mathrm{KH}_{2} \mathrm{PO}_{4}-\mathrm{K}_{2} \mathrm{HPO}_{4}$ buffer $(\mathrm{pH}=9)$. This revealed that the real active cocatalysts in the photocatalytic oxygen evolution are the as-converted hydroxides rather than the starting MOFs owing to their instability in alkaline media. As shown in Fig. 7, $\mathrm{O}_{2}$ evolution with MOF-derived Fe-based cocatalysts increases with irradiation time. For the CoFe-OH-0.75 cocatalyst, the amount of $\mathrm{O}_{2}$ evolved reached $140 \mu \mathrm{mol}$ after irradiation for $80 \mathrm{~min}$, which is higher than that achieved with its FeNi-OH-0.75 (97 $\mu \mathrm{mol})$ and Fe-OH $(66 \mu \mathrm{mol})$ counterparts. Based on the amount of $\mathrm{Na}_{2} \mathrm{~S}_{2} \mathrm{O}_{8}(470 \mu \mathrm{mol})$ used, the evolved $\mathrm{O}_{2}$ yield $\left(\mathrm{O}_{2}\right.$ yield $=2 \times$ moles of $\mathrm{O}_{2} /$ moles of $\mathrm{Na}_{2} \mathrm{~S}_{2} \mathrm{O}_{8}$ ) was calculated to be $59.6 \%$ (CoFe-OH-0.75), $41.3 \%$ (NiFe-OH-0.75), and $28.1 \%(\mathrm{Fe}-\mathrm{OH})$. The $\mathrm{O}_{2}$ yield with the CoFe-OH-0.75 cocatalyst (59.6\%) was also higher than that reported for the $\left[\mathrm{Ru}(\mathrm{bpy})_{3}\right]^{2+}-\mathrm{S}_{2} \mathrm{O}_{8}{ }^{2-}$ system with various other cocatalysts, such as $\left[\mathrm{Fe}^{\mathrm{III}} 4\left(\mathrm{H}_{2} \mathrm{O}\right)_{2}\left(\mathrm{P}_{2} \mathrm{~W}_{15} \mathrm{O}_{56}\right)_{2}\right]^{12-}(48 \%)$ [64],
$\mathrm{Co}_{3} \mathrm{O}_{4} / \mathrm{Co}(\mathrm{OH})_{2}$ hybrids (approximately 25\%) [65], salophen $\mathrm{Cu}(\mathrm{II}) \quad$ complex (approximately 13\%) [66], $\left\{\mathrm{K}_{2}\left[\mathrm{CoO}_{3} \mathrm{PCH}_{2} \mathrm{~N}\left(\mathrm{CH}_{2} \mathrm{CO}_{2}\right)_{2}\right]\right\}_{6}$ complex (46.8\%) [67], and $\left[\mathrm{Cu}_{8}(\mathrm{dpk} \cdot \mathrm{OH})_{8}(\mathrm{OAc})_{4}\right]\left(\mathrm{ClO}_{4}\right)_{4}$ complex (38\%) [68]. These results indicate that the MOF-derived Fe-based hydroxides could serve as efficient cocatalysts for photocatalytic water oxidation by coupling with a photosensitizer.

\section{Conclusions}

Amorphous Fe-based bimetallic hydroxides can be prepared by the in situ chemical transformation of Fe-based bimetallic MOF precursors under alkaline conditions. The as-converted Fe-based bimetallic hydroxides are composed of amorphous ultrasmall nanoparticles and exhibit enhanced electrocatalytic activity for the OER in alkaline media. Furthermore, these MOF-derived Fe-based bimetallic hydroxides could also serve as cocatalysts to couple with the $\left[\mathrm{Ru}(\mathrm{bpy})_{3}\right]^{2+}$ photosensitizer for highly efficient photocatalytic water oxidation. Our study also provides insights for the design and synthesis of highly efficient electro-/photo-catalysts toward water splitting or other energy catalysis applications. Investigations to further enhance the catalytic performance of these MOF-derived materials should focus on rational control of the electronic structure and surface properties by strategies such as element doping, defect engineering, and interface engineering.

\section{Electronic supporting information}

Supporting information is available in the online version of this article

\section{References}

[1] Q. Wang, K. Domen, Chem. Rev., 2020, 120, 919-985.

[2] H. Sun, Z. Yan, F. Liu, W. Xu, F. Cheng, J. Chen, Adv. Mater., 2020, 32, e1806326.

[3] J. Zhu, L. Hu, P. Zhao, L. Y. S. Lee, K. Y. Wong, Chem. Rev., 2020, 120,

\section{Graphical Abstract}

Chin. J. Catal., 2021, 42: 1370-1378 doi: 10.1016/S1872-2067(20)63741-X

\section{In situ formation of amorphous Fe-based bimetallic hydroxides from metal-organic frameworks as efficient oxygen evolution catalysts}

You Xu, Kaili Ren, Rong Xu*

Zhejiang University of Technology, China;

Nanyang Technological University, Singapore

Amorphous Fe-based bimetallic hydroxides can be prepared via the in situ chemical transformation of metal-organic frameworks in alkaline media. The as-converted $\mathrm{Ni}(\mathrm{Co}) \mathrm{Fe}-\mathrm{OH}$ could serve as an efficient catalyst for both electrochemical and photochemical water oxidation. 
851-918.

[4] I. Roger, M. A. Shipman, M. D. Symes, Nat. Rev. Chem., 2017, 1, 0003.

[5] Y. Xu, M. Kraft, R. Xu, Chem. Soc. Rev., 2016, 45, 3039-3052.

[6] W. Zhong, S. Shen, M. He, D. Wang, Z. Wang, Z. Lin, W. Tu, J. Yu, Appl. Catal. B, 2019, 258, 117967.

[7] F. Yu, B.-Q. Hu, X. Xiong, W.-T. Lu, B. Li, Chin. J. Inorg. Chem., 2020, 36, 1873-1880.

[8] B. Zhang, X. Zheng, O. Voznyy, R. Comin, M. Bajdich, M. García-Melchor, L. Han, J. Xu, M. Liu, L. Zheng, F. P. García de Arquer, C. T. Dinh, F. Fan, M. Yuan, E. Yassitepe, N. Chen, T. Regier, P. Liu, Y. Li, P. De Luna, A. Janmohamed, H. L. Xin, H. Yang, A. Vojvodic, E. H. Sargent, Science, 2016, 352, 333-337.

[9] N.-T. Suen, S.-F. Hung, Q. Quan, N. Zhang, Y.-J. Xu, H. M. Chen, Chem. Soc. Rev., 2017, 46, 337-365.

[10] S. Wan, J. Qi, W. Zhang, W. Wang, S. Zhang, K. Liu, H. Zheng, J. Sun, S. Wang, R. Cao, Adv. Mater., 2017, 29, 1700286.

[11] D. Y. Chung, P. P. Lopes, P. Farinazzo Bergamo Dias Martins, H. He, T. Kawaguchi, P. Zapol, H. You, D. Tripkovic, D. Strmcnik, Y. Zhu, S. Seifert, S. Lee, V. R. Stamenkovic, N. M. Markovic, Nat. Energy, 2020, 5, 222-230.

[12] R. Gao, D. Yan, Adv. Energy Mater., 2019, 10, 1900954.

[13] J. Qi, Y. P. Lin, D. Chen, T. Zhou, W. Zhang, R. Cao, Angew. Chem. Int. Ed., 2020, 59, 8917-8921.

[14] X. Gao, D. Chen, J. Qi, F. Li, Y. Song, W. Zhang, R. Cao, Small, 2019, 15, e1904579.

[15] W. Zhong, Z. Lin, S. Feng, D. Wang, S. Shen, Q. Zhang, L. Gu, Z. Wang, B. Fang, Nanoscale, 2019, 11, 4407-4413.

[16] S. Xie, F. Li, S. Xu, J. Li, W. Zeng, Chin. J. Catal., 2019, 40, 1205-1211.

[17] H. G. R. Monestel, I. S. Amiinu, A. A. González, Z. Pu, B. Mousavi, S. $\mathrm{Mu}$, Chin. J. Catal., 2020, 41, 839-846.

[18] W. Feng, H. Chen, Q. Zhang, R. Gao, X. Zou, Chin. J. Catal., 2020, 41, 1692-1697.

[19] Y. Ding, B.-Q. Miao, Y. Zhao, F.-M. Li, Y.-C. Jiang, S.-N. Li, Y. Chen, Chin. J. Catal., 2021, 42, 271-278.

[20] W. Sun, J. Lin, X. Liang, J. Yang, B. Ma, Y. Ding, Acta Phys.-Chim. Sin., 2020, 36, 1905025.

[21] C. Walter, P. W. Menezes, S. Orthmann, J. Schuch, P. Connor, B. Kaiser, M. Lerch, M. Driess, Angew. Chem. Int. Ed., 2018, 57, 698-702.

[22] P. Chen, T. Zhou, L. Xing, K. Xu, Y. Tong, H. Xie, L. Zhang, W. Yan, W. Chu, C. Wu, Y. Xie, Angew. Chem. Int. Ed., 2017, 56, 610-614.

[23] D. Yan, Y. Li, J. Huo, R. Chen, L. Dai, S. Wang, Adv. Mater., 2017, 29, 1606459

[24] Y. Zhao, X. Zhang, X. Jia, G. I. N. Waterhouse, R. Shi, X. Zhang, F. Zhan, Y. Tao, L.-Z. Wu, C.-H. Tung, D. O'Hare, T. Zhang, Adv. Energy Mater., 2018, 8, 1703585.

[25] W. Kurashige, Y. Mori, S. Ozaki, M. Kawachi, S. Hossain, T. Kawawaki, C. J. Shearer, A. Iwase, G. F. Metha, S. Yamazoe, A. Kudo, Y. Negishi, Angew. Chem. Int. Ed., 2020, 59, 7076-7082.

[26] J. Wang, P. Wang, J. Hou, J. Qian, C. Wang, Y. Ao, Catal. Sci. Technol., 2018, 8, 5406-5415.

[27] L. Xie, Q. Liu, X. Shi, A. M. Asiri, Y. Luo, X. Sun, Inorg. Chem. Front., 2018, 5, 1365-1369.

[28] K. Xia, J. Guo, C. Xuan, T. Huang, Z. Deng, L. Chen, D. Wang, Chin. Chem. Lett., 2019, 30, 192-196.

[29] G. Chen, Z. Hu, Y. Zhu, B. Gu, Y. Zhong, H. J. Lin, C. T. Chen, W. Zhou, Z. Shao, Adv. Mater., 2018, 30, e1804333.

[30] H. Xu, B. Fei, G. Cai, Y. Ha, J. Liu, H. Jia, J. Zhang, M. Liu, R. Wu, Adv. Energy Mater., 2019, 10, 1902714.

[31] W. Xing, S. Yin, W. Tu, G. Liu, S. Wu, H. Wang, M. Kraft, G. Wu, R. Xu,
Angew. Chem. Int. Ed., 2020, 59, 1171-1175.

[32] G. Liu, D. He, R. Yao, Y. Zhao, J. Li, Nano Res., 2018, 11, 1664-1675.

[33] H. Yang, Z. Chen, P. Guo, B. Fei, R. Wu, Appl. Catal. B, 2020, 261, 118240.

[34] C. Ray, S. C. Lee, K. V. Sankar, B. Jin, J. Lee, J. H. Park, S. C. Jun, ACS Appl. Mater. Interfaces, 2017, 9, 37739-37749.

[35] B. Lassalle-Kaiser, A. Zitolo, E. Fonda, M. Robert, E. Anxolabéhère-Mallart, ACS Energy Lett., 2017, 2, 2545-2551.

[36] L. Yang, Z. Guo, J. Huang, Y. Xi, R. Gao, G. Su, W. Wang, L. Cao, B. Dong, Adv. Mater., 2017, 29, 1704574.

[37] T. Wang, C. Wang, Y. Jin, A. Sviripa, J. Liang, J. Han, Y. Huang, Q. Li, G. Wu, J. Mater. Chem. A, 2017, 5, 25378-25384.

[38] L. Liardet, X. Hu, ACS Catal., 2017, 8, 644-650.

[39] S. A. Lee, T. H. Lee, C. Kim, M.-J. Choi, H. Park, S. Choi, J. Lee, J. Oh, S. Y. Kim, H. W. Jang, ACS Catal., 2019, 10, 420-429.

[40] W. D. Chemelewski, H.-C. Lee, J.-F. Lin, A. J. Bard, C. B. Mullins, J. Am. Chem. Soc., 2014, 136, 2843-2850.

[41] L. Jiao, Y. Wang, H. L. Jiang, Q. Xu, Adv. Mater., 2018, 30, 1703663.

[42] S. Zhao, Y. Wang, J. Dong, C.-T. He, H. Yin, P. An, K. Zhao, X. Zhang, C. Gao, L. Zhang, J. Lv, J. Wang, J. Zhang, A. M. Khattak, N. A. Khan, Z. Wei, J. Zhang, S. Liu, H. Zhao, Z. Tang, Nat. Energy, 2016, 1, 16184.

[43] J. Duan, S. Chen, C. Zhao, Nat Commun, 2017, 8, 15341.

[44] Q. Wang, D. Astruc, Chem. Rev., 2020, 120, 1438-1511.

[45] Y. Xu, X. Chai, T. Ren, S. Yu, H. Yu, Z. Wang, X. Li, L. Wang, H. Wang, Chem. Commun., 2020, 56, 2151-2154.

[46] F.-L. Li, Q. Shao, X. Huang, J.-P. Lang, Angew. Chem. Int. Ed., 2018, 57, 1888-1892.

[47] D. Senthil Raja, H.-W. Lin, S.-Y. Lu, Nano Energy, 2019, 57, 1-13.

[48] S. Dang, Q.-L. Zhu, Q. Xu, Nat. Rev. Mater., 2017, 3, 17075.

[49] A. Mahmood, W. Guo, H. Tabassum, R. Zou, Adv. Energy Mater., 2016, 6, 1600423.

[50] Y. Xu, W. Tu, B. Zhang, S. Yin, Y. Huang, M. Kraft, R. Xu, Adv. Mater., 2017, 29, 1605957.

[51] Y. V. Kaneti, J. Tang, R. R. Salunkhe, X. Jiang, A. Yu, K. C. Wu, Y. Yamauchi, Adv. Mater., 2017, 29, 1604898.

[52] D. D. Babu, Y. Huang, G. Anandhababu, M. A. Ghausi, Y. Wang, ACS Appl. Mater. Interfaces, 2017, 9, 38621-38628.

[53] J. Tian, F. Jiang, D. Yuan, L. Zhang, Q. Chen, M. Hong, Angew. Chem. Int. Ed., 2020, 59, 13101-13108.

[54] Y. Xia, B. Wang, G. Wang, X. Liu, H. Wang, ChemElectroChem, 2016, 3, 299-308.

[55] M. W. Louie, A. T. Bell, J. Am. Chem. Soc., 2013, 135, 12329-12337.

[56] W. Tian, X. Wang, C. Zhi, T. Zhai, D. Liu, C. Zhang, D. Golberg, Y. Bando, Nano Energy, 2013, 2, 754-763.

[57] Z. Wu, Z. Zou, J. Huang, F. Gao, ACS Appl. Mater. Interfaces, 2018, 10, 26283-26292.

[58] D. Zhou, Z. Cai, Y. Jia, X. Xiong, Q. Xie, S. Wang, Y. Zhang, W. Liu, H. Duan, X. Sun, Nanoscale Horiz, 2018, 3, 532-537.

[59] J. Xu, J. Li, D. Xiong, B. Zhang, Y. Liu, K.-H. Wu, I. Amorim, W. Li, L. Liu, Chem. Sci., 2018, 9, 3470-3476.

[60] H. Jin, S. Mao, G. Zhan, F. Xu, X. Bao, Y. Wang, J. Mater. Chem. A, 2017, 5, 1078-1084.

[61] J. Liu, Y. Ji, J. Nai, X. Niu, Y. Luo, L. Guo, S. Yang, Energy Environ. Sci., 2018, 11, 1736-1741.

[62] X. B. Han, Z. M. Zhang, T. Zhang, Y. G. Li, W. Lin, W. You, Z. M. Su, E. B. Wang, J. Am. Chem. Soc., 2014, 136, 5359-5366.

[63] G. S. Hutchings, Y. Zhang, J. Li, B. T. Yonemoto, X. Zhou, K. Zhu, F. Jiao, J. Am. Chem. Soc., 2015, 137, 4223-4229.

[64] M. Zheng, Y. Ding, X. Cao, T. Tian, J. Lin, Appl. Catal. B, 2018, 237, 1091-1100.

[65] B. Yang, W. Xie, G. Wang, Z. Wang, X. Zhao, C. Yang, X. Su, K. Ma, Mater. Lett., 2020, 262, 127170. 
[66] M. A. Asraf, C. I. Ezugwu, C. M. Zakaria, F. Verpoort, Photochem. Photobiol. Sci., 2019, 18, 2782-2791.

[67] J. Lin, X. Meng, M. Zheng, B. Ma, Y. Ding, Appl. Catal. B, 2019, 241,
351-358.

[68] J. Lin, X. Liang, X. Cao, N. Wei, Y. Ding, Chem. Commun., 2018, 54, 12515-12518.

\title{
金属-有机框架原位转化合成无定形 $\mathrm{Fe}$ 基双金属氢氧化物催化剂 催化析氧反应性能
}

\author{
许 友 ${ }^{\mathrm{a}, \mathrm{b}}$, 任凯丽 ${ }^{\mathrm{a}}$, 徐 蓉, ${ }^{\mathrm{b}}$ \\ $\mathrm{a}^{\mathrm{a}}$ 折江工业大学化学工程学院, 绿色化学合成技术国家重点实验室培育基地, 浙江杭州 310014 , 中国 \\ b南洋理工大学化学与生物医学工程学院, 新加坡637459, 新加坡
}

\begin{abstract}
摘要: 传统化石能源的大量消耗使得能源短缺和环境污染等问题日益严峻. 社会的可持续发展需要进行能源结构调整, 寻 求清洁、可再生的替代能源已迫在眉睫. 氢能作为一种可再生能源, 其热值高, 燃烧产物无污染, 是未来最理想的能源形式 之一. 水裂解制氢是公认的未来清洁制氢的一种有效途径. 然而, 无论是电催化或光催化水裂解反应, 析氧反应都是关键 的半反应. 因其复杂的四电子过程导致动力学缓慢, 使得析氧半反应成为水裂解反应的瓶颈. 长久以来, 贵金属 Ir和Ru基 材料是被广泛研究的高活性的析氧催化剂. 然而高成本和低储量极大地限制了它们的大规模工业化应用. 因此, 开发高 效、储量丰富的析氧催化剂, 意义重大但仍充满挑战性.

本文考察了一种简便而有效的合成策略, 在碱性水溶液条件下,成功实现将一系列 $\mathrm{Fe}$ 基金属有机框架( MOF)前驱物原 位转化为无定形 $\mathrm{Fe}$ 基双金属氢氧化物纳米结构. 这些由MOF前驱物转化得到的氢氧化物纳米结构保留了前驱体纳米棒的 宏观形貌, 由许多超细的无定形纳米颗粒(平均粒径小于 $10 \mathrm{~nm}$ )构成, 在催化反应中可以提供丰富的催化活性位, 相邻的纳 米颗粒之间紧密接触, 有利于电子在催化活性位之间传递. 以玻碳电极作为基底, 通过组分优化得到的 NiFe-OH-0.75催化 剂样品在电催化析氧反应中仅需 $270 \mathrm{mV}$ 的过电位便可达到 $10 \mathrm{~mA} \mathrm{~cm}$ 的电流密度, Tafel斜率为 $39 \mathrm{mV} \mathrm{dec}^{-1}$. 将催化剂负 载到三维泡沫镍基底上时, 由于电极基底导电性提升以及传质增加, 在 $10 \mathrm{~mA} \mathrm{~cm}$ 的电流密度所需的过电位可以降低到 $235 \mathrm{mV}$, Tafel斜率为 $37 \mathrm{mV} \mathrm{dec}{ }^{-1}$, 并且表现出较好的稳定性. 同时, 本文进一步证实这些无定形氢氧化物可以用作助催化 剂, 与合适的光敏剂结合, 实现有效的光催化水氧化反应。在 $\mathrm{KH}_{2} \mathrm{PO}_{4}-\mathrm{K}_{2} \mathrm{HPO}_{4}$ 缓冲溶液 $(\mathrm{pH}=9)$ 体系中, 以 $\left[\mathrm{Ru}\left(2,2^{\prime} \text { '-bipyridine }\right)_{3}\right] \mathrm{Cl}_{2}$ 为光敏剂, $\mathrm{Na}_{2} \mathrm{~S}_{2} \mathrm{O}_{8}$ 为电子受体, 由 CoFe-MIL-0.75前驱体转化所得到的 CoFe-OH- 0.75 助催化剂表现 出更优越的光催化产氧性能, 产氧效率可达 $59.6 \%$. 本文结果可以为其他基于MOF及其相关衍生材料的制备提供新思路.
\end{abstract} 关键词：双金属氢氧化物; 电催化; 金属有机框架; 析氧反应; 光催化

收稿日期: 2020-08-31. 接受日期: 2020-10-22. 上网时间: 2021-04-05.

*通讯联系人. 电子信箱: rxu@ntu.edu.sg

基金来源：南洋理工大学和国家自然科学基金(21701141).

本文的电子版全文由Elsevier出版社在ScienceDirect上出版(http://www.sciencedirect.com/journal/chinese-journal-of-catalysis). 